\title{
INVIABILIDADE DA DESAPOSENTAÇÃO NO REGIME GERAL: Análise Dos Óbices Jurídicos E Procedimentais À Sua Concessão
}

\author{
INVIABILITY OF UNRETIREMENT IN THE GENERAL REGIME: Analysis Of The \\ Legal And Procedural Obstacles To Their Grant
}

Lidiane Dutra Dias ${ }^{1}$

\section{RESUMO}

Este trabalho tem por objetivo analisar a (in)viabilidade jurídica e procedimental do instituto da desaposentação, isto é, da renúncia à aposentadoria concedida para requerer novo benefício mais vantajoso. Para tanto, necessário se fez examinar detidamente a origem e o conceito de desaposentação e, em seguida, os principais argumentos que norteiam a discussão da matéria, promovendo um exame sistêmico dentro do arcabouço previdenciário e constitucional vigente.

Palavras-chave: Aposentadoria. Desaposentação. Inviabilidade jurídica.

\begin{abstract}
This work pretend to analyze the legal and procedural (in)viability of unretirement institute, which means to renounce the retirement and then request another one with more benefits. Therefore, it was necessary to examine the origin and concept of unretirement detail and then the relevant arguments that guide the discussion about the matter, promoting a systemic examination based on the social security and constitutional rules.
\end{abstract}

Keywords: Retirement. Unretirement. Legal inviability.

\section{PREMISSAS INICIAIS}

Em meados do século $X X$, com vistas a evitar a repetição das barbáries ocorridas na Segunda Guerra Mundial, as Constituições dos Estados europeus e

\footnotetext{
${ }^{1}$ Advogada graduada em Direito pela Universidade Federal de Juiz de Fora - UFJF e pós-graduanda em Direito Previdenciário. E-mail: lidiane_dutradias@hotmail.com
} 
americanos passaram a reservar maior importância aos direitos humanos, positivando-os de forma mais ampla, o que garantiu a valorização e a proteção das garantias individuais e sociais, independentemente de sujeição ao governo.

A Constituição, tida inicialmente como mera coadjuvante política, assume, a partir de então, o protagonismo nos mais influentes ordenamentos jurídicos do mundo, atribuindo força valorativa às normas principiológicas. Dessa forma, as leis, que antes serviam de instrumento ao totalitarismo e à desumanidade, passam a ser interpretadas à luz da Lei Fundamental (IBRAHIM, 2011).

Esse movimento, que foi denominado "Neoconstitucionalismo", teve, portanto, por consequência, o enaltecimento do Estado Constitucional pautado na salvaguarda de direitos fundamentais, de modo que o Direito ganhou novas perspectivas mediante inovações hermenêuticas.

Luís Roberto Barroso, em seu artigo "Neoconstitucionalismo e constitucionalização do Direito", ora apontado como marco teórico do presente trabalho, assevera que o substrato para a reconstitucionalização no Brasil foi o processo de redemocratização protagonizado pela publicação da Constituição Federal de 1988, diploma este que provocou acertada transição do regime intolerante e autoritário para o Estado Democrático de Direito (BARROSO, 2005).

Apelidada de Constituição Cidadã, demonstrou especial preocupação com os direitos sociais (direitos fundamentais de segunda dimensão), estabelecendo rol de garantias que estimularam a intervenção do Estado na liberdade individual, a fim de assegurar o bem estar social (Welfare State), conforme se verifica a partir do artigo 6ํ da Magna Carta, no qual se lê: "São direitos sociais a educação, a saúde, a alimentação, o trabalho, a moradia, o transporte, o lazer, a segurança, a previdência social, a proteção à maternidade e à infância, a assistência aos desamparados, na forma desta Constituição".

Como se percebe, a previdência social está inserida neste rol, constituindo, portanto, direito público subjetivo do cidadão. É este o direito social que perpassará toda a análise deste artigo, que se dedica ao estudo da desaposentação, instituto nascido no âmbito do direito previdenciário. 
Segundo levantamento feito pela Advocacia Geral da União, "estima-se que existam hoje em todo o País cerca de 480 mil aposentados ainda trabalhando, cenário este que vem crescendo exponencialmente com a intensa divulgação da tese por escritórios jurídicos especializados" ${ }^{2}$. Ainda de acordo com o órgão, em todo o Brasil, estima-se que ficaram suspensas e aguardando o julgamento do Recurso Extraordinário n 661.256 no Supremo Tribunal Federal cerca de 182,1 mil ações judiciais que versavam sobre a renúncia à aposentadoria com pedido simultâneo de novo benefício mais vantajoso que o anterior por incorporar contribuições previdenciárias posteriores à concessão da primeira aposentadoria.

As razões para números tão significativos são variadas. O baixo valor médio das aposentadorias, a concessão precoce dos benefícios por tempo de contribuição (segundo 0 último Anuário Estatístico da Previdência Social - $A E P S^{3}$, aproximadamente $38 \%$ deles são destinados a segurados na faixa etária dos 50 a 54 anos), a criação do fator previdenciário, o desequilíbrio causado pela inversão da pirâmide etária tendendo a contar com mais inativos do que ativos e, ainda, a extinção do pecúlio e do abono de permanência em serviço ${ }^{4}$ são alguns dos aspectos que contribuíram para a volta dos jubilados à atividade laborativa.

Corolário deste retorno ao mercado de trabalho é a indignação de, não obstante os recolhimentos mensais efetuados pelos aposentados, estes não receberem qualquer contrapartida significativa do INSS. Daí as centenas de milhares de demandas previdenciárias versando sobre a desaposentação.

O hodierno cenário da Previdência Social brasileira convive com sucessivos déficits no fundo previdenciário do Instituto Nacional do Seguro Social - INSS. O Ministério da Fazenda anunciou, em janeiro do corrente ano, saldo deficitário

2 Informação colhida no site da Advocacia Geral da União. Disponível em: <http://www.agu.gov.br/page/content/detail/id_conteudo/398586>. Acesso em: 15 mar 2017.

${ }^{3}$ Anuário Estatístico da Previdência Social 2014.

${ }^{4}$ Pecúlio era a devolução, em parcela única, das contribuições vertidas pelo segurado em favor da Previdência Social nas hipóteses do artigo 81 da Lei oㅡ 8.213/1991, dentre as quais se incluía como beneficiário o aposentado por idade ou por tempo de serviço pelo Regime Geral de Previdência Social que voltasse a exercer a atividade exercida pelo mesmo, quando dele fosse afastado.

Abono de permanência em serviço, por sua vez, consistia no acréscimo ao salário de $25 \%$ do valor da aposentadoria por tempo de serviço a que fazia jus o segurado, por ter ele implementado as condições para recebê-la, mas ter optado por continuar em plena atividade laborativa (art. 87 da Lei ํo 8.213/1991). 
aproximado de 149,73 bilhões no INSS em 2016 (MARTELLO, 2017), razão pela qual a Reforma da Previdência Social, desde que razoável e baseada em cálculos atuariais, torna-se medida imprescindível para assegurar prestações futuras.

É por essas e outras razões que os olhos do governo e da sociedade estavam recentemente voltados para o julgamento do $R E$ n 661.256 no Supremo Tribunal Federal. Isso porque, segundo a $\mathrm{AGU}^{5}$, o reconhecimento da possibilidade da desaposentação geraria um gasto de $R \$ 7,65$ bilhões anuais para os cofres da previdência, o que só agravaria o quadro de crise.

Inobstante o julgamento pelo STF, a matéria continua sendo objeto de discussões acaloradas, especialmente por aqueles que criticam a decisão da Suprema Corte dizendo ter sido esta meramente política.

Assim, o momento não poderia ser mais oportuno para tratar deste tema. É por isso que, considerando a sua relevância prática e teórica, bem como a sua atualidade, o presente trabalho revela-se importante estudo da inviabilidade jurídica e procedimental da desaposentadoria, o que o torna instigante e útil não apenas para a comunidade acadêmica, mas também para os operadores e profissionais do direito em geral.

O objetivo geral deste artigo é, portanto, demonstrar, através de argumentos jurídicos e procedimentais, a impossibilidade da desaposentação no Regime Geral de Previdência Social à luz das normas principiológicas constitucionais e previdenciárias.

Como objetivo específico, pretende-se analisar os principais argumentos favoráveis à desaposentação, apontando seus deslizes e equívocos interpretativos e demonstrando ao leitor a correção do posicionamento contrário à matéria defendido neste trabalho.

A fim de lograrmos êxito neste mister nos utilizaremos do método dedutivo, de maneira que partiremos de premissas teóricas gerais para alcançar os aspectos particulares. Valeremo-nos, para tanto, da investigação jurídica, teórica e legal, em especial no tocante aos aspectos conceituais, doutrinários e jurisprudenciais quanto

\footnotetext{
5 Informação colhida no site da Advocacia Geral da União. Disponível em: <http://www.agu.gov.br/page/content/detail/id_conteudo/398586>. Acesso em: 16 mar 2017.
} 
ao objeto de estudo. Imperioso salientar que o trabalho será, no que diz respeito às áreas de conhecimento jurídico, multidisciplinar, haja vista a necessidade de se buscar institutos relacionados ao Direito Previdenciário, ao Direito do Trabalho, ao Direito Administrativo e, ainda, ao Direito Constitucional.

De início, serão minudenciados os aspectos específicos da desaposentação. Em um primeiro momento, se explorará a origem do instituto, de maneira que o conhecimento histórico contribuirá para melhor percepção do leitor acerca do tema. Em seguida, expor-se-á a conceituação do instituto sob exame, evidenciando, desde logo, as correntes existentes acerca do assunto, quais sejam a favorável sem que seja preciso restituir à Previdência Social os valores pagos na primeira aposentadoria; a favorável com necessária devolução dos referidos valores; e, por fim, a desfavorável à desaposentação.

A partir de então, o foco passará a ser a análise dos argumentos comumente utilizados para acatar a tese de desaposentação, os quais serão rechaçados por apresentarem equívocos interpretativos do ponto de vista dos princípios constitucionais e dos que norteiam o direito previdenciário. Como se demonstrará tais argumentos, em verdade, representam verdadeiros impedimentos à concessão da desaposentadoria.

\section{ORIGEM DA DESAPOSENTAÇÃO}

Considerado o pai do neologismo "desaposentação", Wladimir Novaes Martinez foi o primeiro doutrinador a cogitar a possibilidade técnica deste instituto à luz do ordenamento jurídico brasileiro. Os seus primeiros passos no tema devem-se ao artigo por ele intitulado de "Renúncia e irreversibilidade dos benefícios previdenciários" (MARTINEZ, 1987), no qual o autor pela primeira vez se utilizou da expressão "aposentação".

O trabalho de Martinez que se tornou por demasiado conhecido por seu ineditismo em tratar verdadeiramente da desaposentação foi 0 artigo "Reversibilidade da prestação previdenciária" (MARTINEZ, 1988), apegando-se à 
tese de que a irreversibilidade do direito era uma garantia do segurado e não do INSS, para fundamentar seu posicionamento favorável à matéria (MARTINEZ, 2014).

A partir de então, o instituto passou a ser debatido entre doutrinadores, juristas, acadêmicos e operadores do Direito, os quais contribuíram e ainda hoje contribuem, cada um a seu modo e com suas convicções, para o estudo e desenvolvimento do tema, sobre o qual até o presente momento se paira o dissenso.

Tanto é assim que a matéria chegou, através do Recurso Extraordinário no 661.256, ao Supremo Tribunal Federal e teve reconhecida a sua repercussão geral. Centenas de milhares de ações judiciais foram suspensas até o julgamento do referido recurso, que ocorreu em 27 de outubro de 2016.

A análise dos primórdios da desaposentação necessita fatalmente trespassar a dicção do parágrafo $2^{\circ}$ do artigo 453 da Consolidação das Leis do Trabalho e suas consequências na seara previdenciária.

Para aprofundarmos no assunto, vejamos a redação atribuída ao aludido dispositivo:

Art. 453 - No tempo de serviço do empregado, quando readmitido, serão computados os períodos, ainda que não contínuos, em que tiver trabalhado anteriormente na empresa, salvo se houver sido despedido por falta grave, recebido indenização legal ou se aposentado espontaneamente. (...)

$\S 2^{\circ} \mathrm{O}$ ato de concessão de benefício de aposentadoria a empregado que não tiver completado 35 (trinta e cinco) anos de serviço, se homem, ou trinta, se mulher, importa em extinção do vínculo empregatício. (grifo nosso)

Tal parágrafo $2^{\circ}$, incluído na CLT pela Lei 9.528/1997, concebeu uma nova forma de extinção do contrato de trabalho, a aposentadoria voluntária (TERAN, 2015). Na prática, a nova prescrição celetista instituía, a partir de então, a vedação à continuidade do vínculo empregatício quando do requerimento administrativo da aposentadoria. Dizendo de outro modo, a concessão do benefício ao trabalhador estava agora condicionada à apresentação do seu desligamento do emprego. 
A jurisprudência do Tribunal Superior do Trabalho era também neste sentido, conforme demonstra a Orientação Jurisprudencial no 177 da SDI-1, inserida em 08 de novembro de 2000, fixando que "a aposentadoria espontânea extingue o contrato de trabalho, mesmo quando o empregado continua a trabalhar na empresa após a concessão do benefício previdenciário. Assim sendo, indevida a multa de $40 \%$ do FGTS em relação ao período anterior à aposentadoria".

Com efeito, a nova forma de extinção do vínculo empregatício ia de encontro à interpretação dada ao artigo 49 da Lei no 8.213/1991, que prevê, em seu inciso I, alínea "b", que o benefício será devido a contar da data do pedido administrativo "quando não houver desligamento do emprego" (GAMA, 2016).

Por esta previsão legal, entendia a doutrina e a jurisprudência que o contrato de trabalho permanecia inalterado ainda que o empregado se aposentasse, de modo que, desejando este afastar-se permanentemente do seu ofício, deveria se dirigir à empresa a fim de extinguir a relação trabalhista e receber as verbas rescisórias a que fizer jus. Como se vê, neste dispositivo, o legislador protegeu, acertadamente, a autonomia do Direito Previdenciário em relação ao Direito do Trabalho.

No entanto, a coexistência dessas duas previsões normativas (artigo 453, §2da CLT e artigo 49, inciso I, alínea "b", da Lei no 8.213/1991), sem que uma revogasse expressamente a outra, permanecia gerando todo o tipo de controvérsia.

No ano de 2007, julgando a ADI no $1.721-3^{6}$, a Suprema Corte acabou por sedimentar o entendimento contemplado na Lei no 8.213/1991, declarando a

\footnotetext{
6 “EMENTA: AÇÃO DIRETA DE INCONSTITUCIONALIDADE. ARTIGO $3^{\circ}$ DA MEDIDA PROVISÓRIA № 1.596-14/97, CONVERTIDA NA LEI № 9.528/97, QUE ADICIONOU AO ARTIGO 453 DA CONSOLIDAÇÃO DAS LEIS DO TRABALHO UM SEGUNDO PARÁGRAFO PARA EXTINGUIR O VÍNCULO EMPREGATÍCIO QUANDO DA CONCESSÃO DA APOSENTADORIA ESPONTÂNEA. PROCEDÊNCIA DA AÇÃO.

1. A conversão da medida provisória em lei prejudica o debate jurisdicional acerca da "relevância e urgência" dessa espécie de ato normativo.

2. Os valores sociais do trabalho constituem: a) fundamento da República Federativa do Brasil (inciso IV do artigo $1^{\circ}$ da CF); b) alicerce da Ordem Econômica, que tem por finalidade assegurar a todos existência digna, conforme os ditames da justiça social, e, por um dos seus princípios, a busca do pleno emprego (artigo 170, caput e inciso VIII); c) base de toda a Ordem Social (artigo 193). Esse arcabouço principiológico, densificado em regras como a do inciso I do artigo $7^{\circ}$ da Magna Carta e as do artigo 10 do ADCT/88, desvela um mandamento constitucional que perpassa toda relação de emprego, no sentido de sua desejada continuidade.
} 
ISSN nº 2359-0106

Vol. 4, n. 1, 2017.

inconstitucionalidade do paragrafo $2^{\circ}$ do artigo 453 da CLT, pondo fim, de uma vez por todas, à discussão.

A Orientação Jurisprudencial 177 da SDI-1 foi cancelada pelo Tribunal Superior do Trabalho, que passou a adotar posicionamento oposto na OJ 361, também da SDI-1, que, no mesmo sentido da decisão do STF, atualmente preleciona que "a aposentadoria espontânea não é causa de extinção do contrato de trabalho se o empregado permanece prestando serviços ao empregador após a jubilação. Assim, por ocasião da sua dispensa imotivada, o empregado tem direito à multa de $40 \%$ do FGTS sobre a totalidade dos depósitos efetuados no curso do pacto laboral" (grifo nosso).

Da possibilidade de o beneficiário de aposentadoria continuar trabalhando decorre a obrigatoriedade de permanecer também contribuindo para o sistema previdenciário, nos moldes do artigo 11, parágrafo $3^{\circ}$, da Lei $n^{0}$ 8.213/1991. In verbis:

O aposentado pelo Regime Geral de Previdência Social-RGPS que estiver exercendo ou que voltar a exercer atividade abrangida por este Regime é segurado obrigatório em relação a essa atividade, ficando sujeito às contribuições de que trata a Lei no 8.212 , de 24 de julho de 1991, para fins de custeio da Seguridade Social.

Além da sobredita permissão de que o aposentado mantenha intacto o seu contrato de trabalho (e, por consequência legal, contribua para o INSS), outro fator que contribuiu significativamente para o surgimento da desaposentação foi a

3. A Constituição Federal versa a aposentadoria como um benefício que se dá mediante o exercício regular de um direito. E o certo é que o regular exercício de um direito não é de colocar o seu titular numa situação jurídico-passiva de efeitos ainda mais drásticos do que aqueles que resultariam do cometimento de uma falta grave (sabido que, nesse caso, a ruptura do vínculo empregatício não opera automaticamente).

4. O direito à aposentadoria previdenciária, uma vez objetivamente constituído, se dá no âmago de uma relação jurídica entre o segurado do Sistema Geral de Previdência e o Instituto Nacional de Seguro Social. Às expensas, portanto, de um sistema atuarial-financeiro que é gerido por esse Instituto mesmo, e não às custas desse ou daquele empregador.

5. O Ordenamento Constitucional não autoriza o legislador ordinário a criar modalidade de rompimento automático do vínculo de emprego, em desfavor do trabalhador, na situação em que este apenas exercita o seu direito de aposentadoria espontânea, sem cometer deslize algum.

6. A mera concessão da aposentadoria voluntária ao trabalhador não tem por efeito extinguir, instantânea e automaticamente, o seu vínculo de emprego.

7. Inconstitucionalidade do $\S 2^{\circ}$ do artigo 453 da Consolidação das Leis do Trabalho, introduzido pela Lei n 9.528/97". 
extinção do pecúlio e do abono de permanência em serviço ${ }^{7}$, quando das reformas previdenciárias neoliberais, na primeira metade da década de 1990.

A partir de então, tendo sido extirpadas do ordenamento jurídico tais benesses, o trabalhador jubilado passou a ser amparado tão somente pelos seguintes benefícios: salário-família, salário-maternidade e reabilitação profissional, nos termos dos artigos 18, §º da Lei nำ 8.213/1991 e 103 do Decreto nํㅜ 3.048/1999 - Regulamento da Previdência Social (GAMA, 2016).

Diante deste cenário de significativa redução da proteção social ao aposentado que conservava o vínculo empregatício, a esperança da desaposentação fez com que o instituto ganhasse força.

\section{DEFINIÇÃO DO INSTITUTO}

Frente à total ausência de regulamentação legal no tocante à desaposentação, sua conceituação decorre da reunião de ensinamentos doutrinários e esforços jurisprudenciais. Passemos, portanto, a analisar algumas das definições dadas ao instituto por previdenciaristas, a fim de se observar o consenso pelo menos quanto ao que se tem entendido por desaposentação, já que não é pacífica a sua viabilidade no nosso ordenamento jurídico.

$\mathrm{Na}$ esteira de Wladimir Novaes Martinez - criador do neologismo, como sobredito -, "desaposentação é um ato jurídico praticado pelo órgão gestor de previdência social a pedido do titular, mediante o qual é desconstituída a concessão e a manutenção de um benefício legitimamente concedido, compreendendo renúncia à aposentação em um mesmo regime ou com vistas em transportar o tempo de serviço para outro regime de previdência social visando à melhoria de situação" (MARTINEZ, 2015).

Em obra consagrada nacionalmente, Fábio Zambitte Ibrahim, um dos maiores expoentes do Direito Previdenciário no Brasil, assim preleciona:

\footnotetext{
${ }^{7}$ Vide nota 4
} 
A desaposentação é definida como a reversão da aposentadoria obtida no Regime Geral de Previdência Social, ou mesmo em Regimes Próprios de Servidores Públicos, com o objetivo exclusivo de possibilitar a aquisição de benefício mais vantajoso no mesmo ou em outro regime previdenciário.

Tal vontade surge, frequentemente, com a continuidade laborativa da pessoa jubilada, a qual pretende, em razão das contribuições vertidas após a aposentação, obter novo benefício, em melhores condições, em razão do novo tempo contributivo. (IBRAHIM, 2011)

Por derradeiro, não obstante a exaustividade em se conceituar repetidamente um vocábulo, julgamos imprescindível apresentar também a definição dada ao instituto pelos doutrinadores Carlos Alberto Pereira de Castro e João Batista Lazzari, também em obra referência para o estudo do Direito Previdenciário. No entendimento deles (CASTRO; LAZZARI, 2014),

(...) a desaposentação é o ato de desfazimento da aposentadoria por vontade do titular, para fins de aproveitamento do tempo de filiação em contagem para nova aposentadoria, no mesmo ou em outro regime previdenciário, em regra por ter permanecido em atividade laborativa (e contribuindo obrigatoriamente, portanto) após a concessão daquela primeira aposentadoria.

Diante do exame das conceituações apresentadas, evidencia-se que a desaposentação nada mais é do que a renúncia pelo segurado à aposentadoria que está recebendo para aproveitar o tempo de contribuição em novo benefício, desta vez mais vantajoso do ponto de vista pecuniário, por incorporar a ele recolhimentos previdenciários feitos em período posterior à concessão da primeira aposentadoria.

A lógica é bem simplória. Como o segurado, não obstante já estivesse aposentado, trabalhou e, necessariamente, verteu contribuições em favor do INSS, supostamente teria direito a reaver da autarquia, proporcionalmente, o que foi pago, aumentando o seu salário de benefício.

Dito de outro modo, o objetivo é renunciar à aposentadoria que lhe é paga a fim de requerer novo benefício que, com nova memória de cálculo, inclua os recolhimentos posteriores, elevando, portanto, a renda mensal do segurado (à exceção das situações em que estes recentes recolhimentos não se enquadram nas 
oitenta por cento maiores contribuições, caso em que são desprezados para fins de cálculo do salário de benefício e este permanece inalterado, nos moldes do artigo 29 da Lei no 8.213/1991).

Como é cediço, na prática, trata-se verdadeiramente de substituição de aposentadorias, e não renúncia, como quer parecer com a utilização desta expressão, visto que em momento algum o segurado deixa de perceber o benefício previdenciário.

Insta ressaltar que a desaposentadoria não se confunde com o conceito de revisão. Como aduz Fernando Vieira Marcelo (MARCELO, 2014), falar-se-á em revisão quando, já lhe tendo sido concedida a aposentadoria, o segurado almeja a correção de erros administrativos que influem negativamente em seu salário de benefício, tais como tempo de contribuição não reconhecido, equívoco na apuração da renda mensal inicial ou, ainda, aplicação de índices prejudiciais ao beneficiário.

No instituto ora analisado, o que ocorre é a renúncia do benefício e, ato contínuo, o pedido de nova aposentadoria, desta feita mais benéfica, não havendo, portanto, que se falar em revisão.

Fábio Zambitte Ibrahim aponta a existência de duas modalidades de desaposentação, a depender da identidade ou não entre os regimes previdenciários a que se filiou o segurado após a aposentadoria. Na primeira situação, isto é, quando permanece inalterado o regime previdenciário, o indivíduo se aposenta prematuramente e não sai do mercado de trabalho, vertendo novas contribuições ao sistema pelo mesmo regime. Nesta hipótese, em tese, não seria possível demandar qualquer incremento do benefício ao Poder Público.

No tocante à segunda situação, esta é observada quando o segurado transmuda de regime previdenciário, isto é, jubilado em um regime, o indivíduo continua trabalhando e vertendo cotizações previdenciárias desta feita em outro regime, a exemplo do caso do indivíduo aposentado pelo Regime Geral de Previdência Social que obtém êxito em concurso público, de maneira que se vincula ao Regime Próprio de Previdência. Pelo fato de já gozar de benefício pelo RGPS, em tese, não lhe seria lícita a averbação do tempo de contribuição no RPPS. 
Nestas circunstâncias, conclui Ibrahim, a desaposentação seria a esperança para, na primeira situação descrita, o segurado elevar o seu benefício previdenciário a partir da incorporação das novas contribuições, e na segunda, para tornar legítima a emissão da certidão de tempo de contribuição - CTC, com a consequente averbação no novo regime (IBRAHIM, 2011).

Imperioso esclarecer, desde logo, que o presente trabalho se aterá à primeira modalidade de desaposentadoria, eis que se consubstancia a espécie mais frequentemente encontrada em ações que versam sobre a matéria.

Conforme os ensinamentos do doutrinador Odair Raposo Simões, em sua obra "A Desaposentação sob a Ótica do Direito Atual", três são as correntes que se formaram a partir do estudo do instituto sub examine. São elas: a favorável sem que seja preciso restituir à Previdência Social os valores pagos na primeira aposentadoria; a favorável com necessária devolução dos referidos valores; e, por fim, a desfavorável à desaposentação (SIMÕES, 2013).

O referido autor cita Fábio Zambitte Ibrahim, Carlos Alberto Pereira de Castro e João Batista Lazzari como doutrinadores adeptos à primeira corrente, utilizandose, em suma, do argumento de que se não houve irregularidade na concessão do benefício, não há que se falar em restituição dos valores recebidos pelo jubilado.

Diferentemente, ainda segundo Raposo Simões, os defensores da segunda corrente, a exemplo de Wladimir Novaes Martinez e de Hermes Arrais Alencar, propugnam que a desaposentação deve ser condicionada à restituição dos valores percebidos na primeira aposentadoria, sob pena de desequilíbrio do orçamento da Previdência Social.

Acompanhando a doutrina de Lorena de Mello Rezende Colnago (COLNAGO apud SIMÕES, 2013), para quem o provimento da desaposentação implica o enriquecimento ilícito do segurado, filiamo-nos à última corrente pelas razões que serão expostas no tópico subsequente, no qual traremos a lume os desacertos dos demais posicionamentos.

\section{PRINCIPAIS OBSTÁCULOS À CONCESSÃO}


Com as reflexões realizadas nos itens anteriores, o estudo passa, a partir de agora, à análise da celeuma em torno da viabilidade ou não da desaposentação à luz da realidade jurídica e procedimental que circunda o tema. Neste tópico, ambiciona-se pormenorizar cada um dos argumentos normalmente utilizados pelos defensores do instituto a fim de demonstrar seus deslizes e equívocos e, ao final, convencer o leitor de que não há razão legal, constitucional e estrutural para a procedência das ações que pleiteiam a desaposentação.

\subsection{Ausência de expressa previsão legal}

Iniciamos a argumentação trazendo o elemento principal da tese utilizada pela Suprema Corte para rechaçar o instituto em análise.

Os ministros concluíram, por 7 votos a 4, que "no âmbito do Regime Geral de Previdência Social (RGPS), somente lei pode criar benefícios e vantagens previdenciárias, não havendo, por ora, previsão legal do direito à desaposentação", conforme se pode extrair do andamento processual do RE $n^{\circ} 661.256$, no site do $\mathrm{STF}^{8}$.

De fato, as normas de direito brasileiro sempre silenciaram sobre a possibilidade de desaposentação, isto é, a desconstituição da aposentadoria por vontade própria do jubilado a fim de que, requerendo novo benefício, este lhe fosse concedido em valor maior do que aquele que lhe era pago, sob a justificativa de, não obstante aposentado, ter vertido novas contribuições aos cofres da Previdência Social.

Constituição Federal, Lei de Benefícios da Previdência Social (Lei no 8.213/1991), Regulamento da Previdência Social (Decreto nำ 3.048/1999), nada tratou de regulamentar o tema, razão pela qual tem gerado, há anos, repetidas discussões em âmbito acadêmico, doutrinário e jurisprudencial.

\footnotetext{
${ }^{8}$ Disponível em:

$<$ http://www.stf.jus.br/portal/processo/verProcessoAndamento.asp?incidente=4157562>. Acesso em 15 mar 2017.
} 
Também no plano do Poder Legislativo os debates acerca da desaposentação são constantes, eis que sucessivos projetos de lei foram apresentados - apesar de nenhum ter ainda obtido o êxito de se concretizar em lei-, tanto na Câmara dos Deputados como no Senado Federal, todos, até o presente momento, pretendendo permitir a renúncia da aposentadoria com a solicitação de novo benefício idêntico ao primeiro, a não ser pela memória de cálculo, que repercute positivamente na renda mensal do segurado. Citem-se como exemplos na Câmara dos Deputados o PL 7.154/2002, o PL 2.682/2007 e o PL 1.168/2011, e no Senado Federal o PL 91/2010.

Recentemente, a publicação da Lei № 13.183, em 4 de novembro de 2015, por pouco não colocou fim à questão. Isso porque seu artigo $6^{\circ}$, que pretendia alterar a Lei o 8.213/1991, fazia expressa menção ao direito do trabalhador jubilado de requerer o recálculo de sua aposentadoria para nele incorporar todo o período contributivo e o valor dos seus salários de contribuição, assegurando-Ihe uma aposentadoria mais vantajosa.

Ocorre que, acertadamente, a então Presidenta da República vetou o aludido dispositivo normativo, utilizando como justificativa a contrariedade aos pilares do sistema previdenciário brasileiro, mormente por seu financiamento intergeracional e por adotar o regime de repartição simples ${ }^{9}$, o que será explorado nos itens subsequentes.

O que nos interessa, por ora, é demonstrar que há total ausência de previsão normativa da desaposentação, não obstante muitas tenham sido as tentativas direcionadas à sua regulamentação.

Por causa de tal omissão, parte da doutrina e da jurisprudência vem sustentando que, se não há vedação legal e constitucional ao instituto, ele deve ser permitido, eis que, conforme dita o inciso II do artigo $5^{\circ}$ da Constituição Federal de 1988, "ninguém é obrigado a fazer ou deixar de fazer alguma coisa senão em virtude de lei". É o que se denomina princípio da legalidade.

9 Disponível em: <http://www.planalto.gov.br/ccivil_03/_Ato2015-2018/2015/Msg/VEP-464.htm>. Acesso em: 16 maio 2016. 
Filiando-se a tal posicionamento, Fábio Zambitte Ibrahim assevera que

Após a análise dos principais aspectos da desaposentação, é inevitável concluir-se pela sua legitimidade, seja perante a Constituição, ou mesmo sob o aspecto legal, inexistindo qualquer vedação expressa à opção pelo segurado em desfazer seu ato concessório do benefício previdenciário da aposentadoria, desde que visando prestação melhor, seja no mesmo ou em outro regime previdenciário.

A hermenêutica previdenciária impõe o entendimento mais favorável ao segurado, desde que tal não implique contrariedade à lei ou despesa atuarialmente imprevista. A desaposentação não possui tais impedimentos. Ainda, a ausência de previsão legal permitindo a desaposentação não é obstáculo, pois aos aposentados é permitida qualquer conduta não vedada pela lei ou Constituição. (IBRAHIM, 2011)

Autores que defendem o instituto em análise olvidam-se, porém, de um importante detalhe.

Ao se aplicar o princípio da legalidade, é preciso levar em conta sua dúplice faceta. Como nos ensina a doutrinadora Fernanda Marinela, em seu manual de Direito Administrativo, existe a legalidade para o direito privado e a legalidade para o direito público. No primeiro caso, as relações jurídicas estabelecem-se entre particulares na ânsia por satisfazerem interesses próprios, de modo que lhes é permitido fazer tudo aquilo que não for proibido pela lei. Por outro lado, na segunda faceta, o que se privilegia é o interesse público, sendo lícito à Administração Pública fazer estritamente o que a lei autorizar ou determinar (MARINELA, 2012).

A limitação à atuação do Estado está evidenciada no artigo 37, caput, da Constituição Federal, alterado pela Emenda Constitucional ํㅜ 19/1998, compondo os princípios básicos que norteiam o Poder Público. In verbis:

Art. 37. A administração pública direta e indireta de qualquer dos Poderes da União, dos Estados, do Distrito Federal e dos Municípios obedecerá aos princípios da legalidade, impessoalidade, moralidade, publicidade e eficiência (...) 
Uma vez que a relação jurídico-previdenciária possui caráter eminentemente público, é certo que ela se sujeita aos padrões de legalidade atinentes ao direito público.

Dessa forma, forçoso concluir que, estando a Administração Pública vinculada à vigência de norma jurídica que the autorize ou determine a atuação, o Instituto Nacional do Seguro Social - INSS não pode, em hipótese alguma, agir no sentido de deferir os pedidos de desaposentação, pois, diante da inexistência de dispositivo normativo que mencione ou regulamente o tema, se o fizesse, estaria afrontando o princípio constitucional da legalidade.

\subsection{Solidariedade do sistema de custeio}

Implícito na Constituição Federal de 1988, o princípio da solidariedade constitui um dos postulados fundamentais da seguridade social brasileira.

Na lição de Sérgio Pinto Martins, "ocorre solidariedade na Seguridade Social quando várias pessoas economizam em conjunto para assegurar benefícios quando as pessoas do grupo necessitarem. As contingências são distribuídas igualmente a todas as pessoas do grupo. Quando uma pessoa é atingida pela contingência, todas as outras continuam contribuindo para a cobertura do necessitado" (MARTINS, 2009).

O princípio da solidariedade tem por fundamento a ideia de que a população economicamente ativa deve contribuir para o sustento daqueles que estão inativos aposentados e pensionistas -, de modo que se alcance o almejado bem estar coletivo.

Em que pese não constar expressamente, há significativo consenso de que a solidariedade emana do caput do artigo 195 da Carta Magna, que prevê, ipsis verbis: 
Distrito Federal e dos Municípios, e das seguintes contribuições sociais:

I - do empregador, da empresa e da entidade a ela equiparada na forma da lei, incidentes sobre:

a) a folha de salários e demais rendimentos do trabalho pagos ou creditados, a qualquer título, à pessoa física que lhe preste serviço, mesmo sem vínculo empregatício;

b) a receita ou o faturamento;

c) o lucro;

II - do trabalhador e dos demais segurados da previdência social, não incidindo contribuição sobre aposentadoria e pensão concedidas pelo regime geral de previdência social de que trata o art. 201;

III - sobre a receita de concursos de prognósticos.

IV - do importador de bens ou serviços do exterior, ou de quem a lei a ele equiparar. (grifo nosso)

Decorrência do princípio da solidariedade, as contribuições previdenciárias têm por fato gerador o exercício de atividade remunerada e destinam-se ao custeio do sistema. Como se infere do artigo supra, a tributação incide, inclusive, sobre o rendimento dos empregados, pelo que se conclui - ainda mais claramente a partir da leitura do artigo $11, \S 3^{\circ}$, da Lei ํo 8.213/1991, como já explicado - que, ainda que aposentado, o trabalhador permanece obrigado a verter contribuições para a previdência social.

Estes recolhimentos feitos em nome do jubilado que não cessou a atividade laboral apenas se justificam pelo fato de a seguridade social brasileira ser baseada no princípio da solidariedade. Significa dizer que o beneficiário de aposentadoria que, por razões pessoais, decide continuar trabalhando, é obrigado a verter as contribuições para o INSS especificamente por estar submetido a sistema em que todos contribuem em favor de todos (BONATO, 2013).

E é exatamente esse caráter mutualista e comutativo da seguridade social, assegurado juridicamente pelo mandado de otimização que ora analisamos, qual seja, o princípio da solidariedade, que nos permite rechaçar veementemente a tese dos defensores da desaposentação. Luiz Henrique Picolo Bueno é um destes. Para ele, “(...) admitindo-se a aplicação do princípio da solidariedade, mesmo assim, não se pode estendê-lo ao ponto de tributar segurado que não poderá auferir em tese nada de substancial em contrapartida. A solidariedade tem limites no princípio da 
razoabilidade. Não é por outro motivo que o art. 201, parágrafo 11, da Constituição Federal prevê a relação entre salários-de-contribuição e salário-benefício. O absurdo tributário neste caso é grave - cobrança de quem não se coloca à disposição um mínimo de prestações que justifique a exação; isto é, para os aposentados que retornam à atividade, inexiste plano previdenciário mínimo" (BUENO, 2012).

Ora, o leitor atento certamente já concluiu que esta arguição é, no mínimo, ilógica.

Em que pese admitirem a solidariedade do sistema previdenciário brasileiro, esses autores a afastam ante a suposta ofensa à razoabilidade. Ocorre que, como se vê, trata-se de ardilosa manobra para burlar a solidariedade em que se baseia o sistema previdenciário.

Em verdade, no trecho supra resta clarividente a falta de argumentação para defender essa posição. O que está aí retratado é a mera insatisfação do autor diante do fato de o aposentado contribuir sem obter qualquer benefício pessoal significativo com isso. Todavia, é justamente essa a essência da solidariedade social. As pessoas contribuem não para si, mas para o sistema como um todo. Como veremos no tópico seguinte, inclusive, as cotizações destinam-se a fundo único para todos os contribuintes, não havendo individualização.

Aceitar argumentação como essa seria a mesma coisa que permitir, por exemplo, que um aposentado, em qualquer situação, se dirigisse à agência do INSS e depositasse em favor da autarquia montantes bem superiores aos que recolheu por toda a vida laboral, com o único intuito de elevar sua renda mensal, o que the seria deferido, pois, por essa lógica, não é razoável impedi-lo de receber aquilo que pagou. Porém, isso seria totalmente contrário à boa-fé e ao caráter solidário da previdência.

A solidariedade social é corroborada pelo sistema previdenciário, na medida em que a legislação inclui a pessoa jurídica como contribuinte, não obstante jamais ocupe a posição de beneficiária da previdência social. Outra evidência é a inexistência de proporcionalidade entre o quantum vertido em contribuições pelo segurado e o benefício que futuramente fará jus. Fosse sistema que estabelecesse esta vinculação de modo diretamente proporcional, seria correto dizer que se o 
aposentado contribuiu, ele deve receber o valor de volta em forma de benefício mais vantajoso. Neste caso, não haveria que se falar em caráter solidário. Ocorre que essa não é a realidade do ordenamento jurídico pátrio.

Passemos agora à análise do regime de repartição adotado como regra na previdência social brasileira. Não obstante decorrer do princípio da solidariedade, o abordaremos em tópico separado diante de sua relevância.

\subsection{Incompatibilidade com o regime de repartição simples}

Diversos são os regimes de financiamento dos capitais utilizados para 0 pagamento das prestações atuais e vindouras da previdência social. Os principais resumem-se em três: regime de repartição simples, regime de repartição de capitais de cobertura e regime de capitalização.

De um modo geral, repartição e capitalização se distinguem, conforme os ensinamentos de Wladimir Novaes Martinez, pelo fato de naquela a totalidade das contribuições ser encaminhada para fundo único, e nesta os recolhimentos previdenciários serem canalizados para conta individualizada em nome do segurado (MARTINEZ, 2015).

Ainda segundo o autor supramencionado, a diferença entre as modalidades de regime de repartição é que, na repartição simples, são captados, no mesmo exercício financeiro, os capitais suficientes para satisfazer todas as despesas daquele ano. Por outro lado, na repartição de capitais de cobertura, as contribuições do ano (receita) são alocadas de modo a garantir o pagamento dos benefícios iniciados no exercício.

No Brasil, o regime de financiamento adotado pelo Regime Geral de Previdência Social e pelo Regime Próprio dos Servidores Públicos é o de repartição simples, ao passo que a Previdência Complementar ou Privada acompanha a lógica do regime de capitalização. Esse modelo brasileiro vai ao encontro da atual tendência das previdências sociais mundo afora que é o sistema de pilares, que supera a noção de uma única forma de custeio. 
Assim sendo, para tratarmos da desaposentação no RGPS, objeto deste trabalho, o nosso foco passa a ser o modelo da repartição simples.

Asseveram Carlos Alberto Pereira de Castro e João Batista Lazzari que,

no sistema de repartição, as contribuições sociais vertem para um fundo único, do qual saem os recursos para a concessão de benefícios a qualquer beneficiário que atenda aos requisitos previstos na norma previdenciária. A participação do segurado continua sendo importante, mas a ausência de contribuição em determinado patamar não lhe retira o direito a benefícios e serviços, salvo nas hipóteses em que se lhe exige alguma carência. Como salienta Feijó Coimbra, este modelo repousa no ideal de solidariedade, no pacto entre gerações - já que cabe à atual geração de trabalhadores em atividade pagar as contribuições que garantem os benefícios dos atuais inativos, e assim sucessivamente, no passar dos tempos -, ideia 82/1881 lançada no Plano Beveridge inglês, e que até hoje norteia a maior parte dos sistemas previdenciários no mundo. (CASTRO; LAZZARI, 2014)

Neste modelo de previdência social, os recolhimentos previdenciários de trabalhadores, empregadores, Poder Público e outras fontes de custeio formam uma unidade de recursos que serão usados para custear os benefícios dos inativos. $O$ sistema está pautado, assim, no pacto intergeracional, de modo que a geração economicamente ativa contribui para o INSS a fim de manter as prestações pagas àqueles que estão na inatividade (DALLEASTE, 2014).

Como sobredito este regime tem estreita relação com o princípio da solidariedade. Isso porque se baseia na solidariedade entre os participantes, ou seja, os segurados da ativa contribuem para que seja possível o pagamento dos benefícios dos inativos. Aqueles segurados da ativa, ao chegarem à inatividade, serão sustentados pelos novos ativos, que recolherão as contribuições previdenciárias para a quitação dos benefícios dos inativos, formando verdadeiro ciclo que tem sido denominado pacto entre gerações.

Essa ideia tem sido agravada, porém, pela inversão da pirâmide etária. Isso se deve ao fato de o pacto intergeracional basear-se na estabilização da pirâmide com as seguintes características: o número de integrantes da população 
economicamente ativa seria sempre maior do que o de inativos. Ocorre que essa realidade vem se alterando significativamente, de modo que a pirâmide etária brasileira caminha no sentido inverso, ou seja, a tendência é que há alguns anos os ativos sejam em menor número do que a população economicamente inativa. Essa estimativa pessimista é justificada pelo envelhecimento da sociedade brasileira.

Diante dessas informações, ousamos discordar daqueles que sustentam a desaposentação alegando que “(...) se o aposentado faz parte do polo dos inativos não pode ele continuar a contribuir após a concessão de sua aposentadoria. Se a lógica é de que os ativos contribuem para que os inativos possam ver garantidos os benefícios previdenciários, estaria o aposentado financiando a sua própria aposentadoria. Isso descaracteriza completamente o sistema adotado pelo Brasil, pois estariam financiando a si próprios" (ALVES; GOUVEIA, 2015).

Teses como essa, data venia, parecem se esquecer de que o sistema previdenciário brasileiro adotou o regime de repartição simples e que, portanto, não se baseia na individualidade. Não há relação direta entre custeio e benefício de cada segurado.

O jubilado que não cessa o vínculo empregatício é, por isso, ativo, não obstante aposentado, eis que permanece contribuindo para o sistema previdenciário. Frise-se: as contribuições são vertidas para o sistema como um todo, não há individualização deste capital em favor do segurado. Por isso, é errôneo dizer que ele estaria financiando seu próprio benefício.

\subsection{Aposentadoria enquanto ato jurídico perfeito}

Em que pese o tema da desaposentadoria faticamente ter por objeto 0 aposentado que não cessa seu vínculo empregatício e, portanto, contribui para o sistema previdenciário, a questão jurídica do problema basicamente se resume em saber se é possível ou não a desconstituição da aposentadoria. É a esta análise que se dedica este tópico e o subsequente.

O Estado, no exercício de suas atribuições, reconhece através da concessão da aposentadoria uma situação jurídica subjetiva - o direito do segurado a receber o 
benefício -, materializando-a por meio de ato administrativo, o qual, necessariamente, deve observar todos os preceitos legais. Este ato tem aptidão para produzir efeitos não somente na seara administrativa, mas também no âmbito jurídico, consubstanciando-se, portanto, ato jurídico perfeito.

Como preleciona Celso Antônio Bandeira de Mello, "o ato administrativo é perfeito quando esgotadas as fases necessárias à sua produção. Portanto, o ato perfeito é o que completou o ciclo necessário à sua formação" (MELLO apud IBRAHIM, 2011).

Pilar da segurança jurídica no nosso Estado Democrático de Direito, o ato jurídico perfeito, aliado ao direito adquirido e à coisa julgada, é direito fundamental expressamente salvaguardado no artigo 5ำ, inciso XXXVI, da Constituição Federal de 1988. Assim, o ato que concedeu a aposentadoria, enquanto ato jurídico perfeito, conta com significativa proteção jurídica (DALLEASTE, 2014).

Para que seja legítima a desaposentação, necessário se faz que o aludido ato concessório possa ser desfeito, retornando o segurado ao status quo ante. Entretanto, há divergência quanto a essa possibilidade.

Carla Martins Alves sintetiza adequadamente a argumentação dos adeptos à tese da desaposentação:

Tais institutos [direito adquirido e ato jurídico perfeito] são meios de proteção do cidadão e não podem ser utilizados como justificativa para prejudicá-lo, em proveito do Estado. Cabe ao próprio titular do direito fazer juízo de conveniência em adotar ou não determinada conduta e não ao ente estatal, ou seja, é uma prerrogativa do cidadão-segurado e não do Estado. Portanto não caberia a este impedir tal pretensão utilizando-se de uma garantia constitucional do próprio pretendente. (ALVES, 2009)

O que, em outras palavras, esses doutrinadores querem dizer é que o ato jurídico perfeito é garantia do cidadão contra o Estado, ainda que isso importe no que chamam de "flexibilização da segurança jurídica" (DALLEASTE, 2014). No entanto, essa "permissão" à inobservância do ato jurídico perfeito apenas quando for 
benéfica ao segurado não encontra qualquer guarida legal ou constitucional. A violação do ato jurídico perfeito, neste caso, põe em risco a própria segurança jurídica da relação previdenciária.

Ora, quer dizer que se for para melhorar a vida do segurado, tudo está permitido, até mesmo desrespeitar a segurança jurídica? De modo algum. Afinal, a garantia expressa no artigo $5^{\circ}$, inciso XXXVI, da Lei Maior, destina-se não só ao cidadão, mas também ao Poder Público, representado, in casu, pelo INSS. Não fosse assim, o Estado estaria totalmente vulnerável a abusos de todo o gênero.

É imprescindível que a garantia constitucional supra seja bilateral, protegendo tanto a pessoa jurídica de direito público - o INSS - como a pessoa física - o aposentado. Dessa forma, a este é atribuída a confiança legítima de que não será alcançado por situação futura desfavorável, assim como essa bilateralidade resguarda de despesas imprevistas o Poder Público e a coletividade que contribui para o sistema. Há, por esse motivo, pode-se dizer, interesse público na negativa da desaposentação.

\subsection{O propósito ilegítimo por detrás da possibilidade de renúncia à percepção do benefício}

Argumento principal em favor da desaposentadoria consiste, justamente, na possibilidade de renúncia ao benefício concedido. Arguem os defensores do instituto que o beneficiário não é obrigado a permanecer aposentado contra sua vontade.

De fato, como se demonstrará neste tópico, a aposentadoria é direito disponível, ante o seu caráter patrimonial, razão pela qual o segurado pode dela livremente abrir mão. Com essa afirmativa, não pretendemos esquecer toda a argumentação exposta até este ponto do trabalho e aderirmos à corrente favorável ao instituto em exame. Em verdade, estamos apenas constatando uma realidade: é perfeitamente lícito ao beneficiário manifestar desejo no sentido de renunciar aos valores mensais pagos a título de aposentadoria. 
O objetivo aqui não é nos imobilizarmos na oposição cega à desaposentação, mas sim construirmos, a partir de ampla visão do assunto, raciocínio que conduza naturalmente à inviabilidade daquela. É por isso que, neste tópico, a pretensão é evidenciar que, não obstante seja concebível a renúncia, esta se torna impraticável frente à impossibilidade de requerer o novo benefício mais vantajoso.

Passemos, então, a dissecar a questão da renúncia aos valores percebidos pelo beneficiário.

Nas palavras de Wladimir Novaes Martinez, "renúncia é a abdicação de um direito pessoal disponível que não cause prejuízos para terceiros. Não é sinônimo de desaposentação, a qual, no comum dos casos, exige uma nova aposentação" (MARTINEZ, 2015).

O INSS, em sua defesa, vem alegando não ser possível a desaposentadoria ante o fundamento normativo previsto no Regulamento da Previdência Social (CASTRO; LAZZARI, 2014). Este diploma foi publicado na forma do Decreto no 3.048/1999, o qual, em seu artigo 181-B, aponta expressamente a irrenunciabilidade dos benefícios, prescrevendo que: "As aposentadorias por idade, tempo de contribuição e especial concedidas pela previdência social, na forma deste Regulamento, são irreversíveis e irrenunciáveis".

Acompanhando o posicionamento de Sérgio Pinto Martins, entendemos que o decreto supramencionado extrapolou os seus limites ao regulamentar o que não tem previsão na lei, o que o torna nulo nesta parte. Isso porque os poderes conferidos ao presidente da República, através do artigo 84, inciso IV, da Constituição Federal de 1988, restringem-se à complementariedade à lei posta, ou seja, não pode o decreto executivo pretender inovar a ordem jurídica criando direitos, obrigações ou proibições à revelia das disposições da lei que regulamenta, em virtude do princípio da legalidade (MARTINS, 2009).

Além do ponto de vista formal, a redação do artigo 181-B do RPS é indefensável também sob a perspectiva material. $\mathrm{O}$ dispositivo normativo aludido se torna ainda mais insustentável quando lembramos que a alteração da situação de "ativo" para "inativo" - para utilizar os termos previdenciários - pressupõe expressa manifestação de vontade do interessado. 
A partir do momento em que o segurado implementa todos os requisitos de elegibilidade previstos em lei para a obtenção da aposentadoria, ele faz jus ao seu recebimento. Entretanto, para que essa concessão se efetive, mister se faz que o indivíduo requeira administrativamente o benefício. Neste sentido, se se atribui plena liberdade ao interessado para promover a constituição de sua aposentadoria após a implementação das condições, da mesma maneira deve lhe ser atribuído o direito de desconstituí-la a partir da renúncia.

Como se percebe, seria forçoso sustentar a irrenunciabilidade da aposentadoria, eis que esta é facilmente refutável pelos problemas de cunho formal e material apresentados pelo artigo 181-B. Assim, o primeiro ato para que possamos pensar em desaposentação - a desconstituição do ato concessivo da aposentadoria - é, de fato, válido.

Contudo, o propósito que se almeja alcançar com esta renúncia, qual seja a concessão de novo benefício monetariamente mais vantajoso, não encontra respaldo nos princípios constitucionais e nos relativos à previdência social.

O que o jubilado pretende com a renúncia não é a desconstituição pura e simples do benefício, até porque, se assim o fosse, ela seria perfeitamente legítima, como restou explanado.

Verdadeiramente, o que se aspira por detrás do desfazimento do ato de concessão da aposentadoria é a incorporação à memória de cálculo das contribuições previdenciárias recolhidas em momento posterior à aposentação para que a renda mensal do novo benefício seja elevada. Isso, entretanto, fere de morte a segurança jurídica do ato concessivo de aposentadoria, prejudicando o outro lado da relação jurídico-previdenciária, que no caso é o Estado.

Em suma, a renúncia pelo aposentado aos valores que vem recebendo a título de aposentadoria (frise-se que não se trata de disposição do próprio benefício ou do tempo de contribuição!) é absolutamente válida, porém inútil, já que não se admite concessão de novo benefício em prejuízo do INSS, tal como se pretende no instituto da desaposentação.

\subsection{Inviabilidade atuarial}


Especial atenção é dedicada ao princípio do equilíbrio atuarial na relação jurídico-previdenciária. Isso se deve ao fato de que eventual descompasso entre as reservas matemáticas arrecadadas a título de contribuições previdenciárias e o quantum retirado para a quitação das prestações mensais aos beneficiários, comprometeria todo o sistema. Por isso, a equação decorrente do pacto entre gerações deve ser rigorosamente bem definida e verificada periodicamente.

Por ser basilar ao sistema previdenciário, o princípio vem expressamente contemplado na Constituição Federal de 1988, a qual, no caput dos artigos que fundamentam os Regimes Próprio e Complementar, estabelece que:

Art. 40. Aos servidores titulares de cargos efetivos da União, dos Estados, do Distrito Federal e dos Municípios, incluídas suas autarquias e fundações, é assegurado regime de previdência de caráter contributivo e solidário, mediante contribuição do respectivo ente público, dos servidores ativos e inativos e dos pensionistas, observados critérios que preservem o equilíbrio financeiro e atuarial e o disposto neste artigo.

Art. 202. O regime de previdência privada, de caráter complementar e organizado de forma autônoma em relação ao regime geral de previdência social, será facultativo, baseado na constituição de reservas que garantam o benefício contratado, e regulado por lei complementar. (grifo nosso)

$\mathrm{Na}$ mesma toada, a Lei Maior também se refere ao equilíbrio financeiro e atuarial quando trata do Regime Geral de Previdência Social, que é o que mais nos interessa para os fins a que se destina o presente trabalho. Senão vejamos:

Art. 201. A previdência social será organizada sob a forma de regime geral, de caráter contributivo e de filiação obrigatória, observados critérios que preservem o equilíbrio financeiro e atuarial, e atenderá, nos termos da lei, a (...). (grifo nosso) 
Iniciemos fazendo a necessária diferenciação entre o equilíbrio financeiro e o equilíbrio atuarial. Aquele se liga à noção de reservas matemáticas para o cumprimento das obrigações assumidas para com os segurados e assistidos pelo sistema; por sua vez, este está associado à atuária propriamente dita, enquanto análise de fatores que interferem no valor do montante assegurado (taxas de contribuição, expectativa de vida, idade da massa etc.).

Neste tópico, vamos nos ater à ideia veiculada pelo equilíbrio atuarial, o qual vem sendo definido por Wladimir Novaes Martinez do seguinte modo: "é uma relação econômica que envolve e vincula o nível das entradas e saídas, sopesando o passado (as obrigações em cumprimento), o presente dos contribuintes e o futuro (benefícios novos a conceder)" (MARTINEZ, 2015).

A preocupação aqui é que o conjunto normativo e técnico seja organizado de tal maneira que haja previsão, a longo prazo, das despesas correntes e, também, das receitas advindas das contribuições pelos financiadores do sistema, de modo a garantir os futuros benefícios.

Não obstante todo o esforço empreendido pelos adeptos à corrente favorável à desaposentação no sentido de que as novas cotizações decorrentes da permanência do aposentado no mercado de trabalho formam nova poupança previdenciária fictícia, salta aos olhos o evidente desequilíbrio atuarial provocado no RGPS caso se admita o instituto.

Sequer é preciso cálculo matemático para perceber 0 descompasso provocado. Isso porque se trata de despesa não prevista no orçamento estatal. $O$ contribuinte faz recolhimentos direcionados a fundo previdenciário nacional comum a todos os segurados do INSS, e não a conta particularizada, como já foi largamente explorado nos itens anteriores.

Às vezes, a própria norma obriga o adiamento da aposentação para garantir o equilíbrio atuarial, como é o caso, por exemplo, do fator previdenciário. Outrossim, oferecendo o sistema tanto a aposentadoria proporcional como a integral, a opção do segurado pelo recebimento de benefício de menor valor, mas durante tempo maior não pode ser alterada a torto e a direito à revelia dos interesses da parte 
contrária (INSS), sob pena de configuração de enriquecimento ilícito do beneficiário, como defende Lorena de Mello Rezende Colnago:

É de suma relevância lembrar que um fato jurídico ingressa no mundo jurídico através de um suporte que, geralmente, é uma norma. No caso da aposentadoria, o fato natural: inatividade remunerada pelos cofres públicos torna-se jurídica e exigível através de um ato administrativo vinculado: aposentação, que necessita de um agente capaz, de expressa previsão legal, de objeto lícito e moral, além do interesse público. Assim, para que o fato jurídico aposentadoria seja retirado do ordenamento, pelo princípio da paridade das formas, necessário se fará um outro ato administrativo vinculado: 0 ato da desaposentação, com requisitos idênticos à emissão do ato de aposentação, veículo introdutor da aposentadoria. Embora haja o interesse do segurado, no caso da desaposentação, não há interesse público, previsão legal, e, nem mesmo, objeto lícito e mora - face à aferição de vantagem em detrimento do equilíbrio financeiro dos Regimes de Previdência, ou seja, o enriquecimento ilícito do segurado. (COLNAGO, 2005)

Neste ponto, imperioso analisar questão comum às correntes que propugnam a viabilidade da desaposentação: a necessidade ou não de devolução dos valores percebidos pelo segurado na vigência da primeira aposentadoria.

Dentre os autores que são favoráveis à restituição, encontram-se nomes como o de Sérgio Pinto Martins, Wladimir Novaes Martinez, Carlos Alberto Pereira de Castro e João Batista Lazzari. A alegação é a de que haveria desequilíbrio atuarial e consequente enriquecimento ilícito do segurado caso as parcelas recebidas na primeira aposentadoria não fossem devolvidas. Assim, a restituição ao erário de tais valores configuraria conditio sine qua non para a procedência da desaposentação (MARTINEZ, 2015).

De outro lado, a corrente encabeçada por Fábio Zambitte Ibrahim e Marco Aurélio Serau Júnior defende a desnecessidade da devolução das prestações recebidas a título de aposentadoria, por se tratar de verba alimentar, pela presunção de boa-fé do segurado e pela ausência de irregularidade na concessão do benefício.

Limitar-nos-emos a dizer que, para os fins deste trabalho, essa dicotomia não nos interessa, eis que sequer acreditamos na possibilidade da concessão de nova 
aposentadoria mais favorável, indo ao encontro do que fixou o julgamento do Recurso Extraordinário ํㅜ 661.256 pelo STF.

\subsection{Inviabilidade procedimental}

O que expusemos até aqui dispensaria argumentos outros na tentativa de convencer o leitor de que a tese da desaposentação não se sustenta. Todavia, vale a pena mostrar um ponto de vista mais prático.

Considerando, por hipótese, a constitucionalidade da renúncia da aposentadoria pelo segurado com o intuito único de requerer novo benefício mais vantajoso que o anterior, tendo em vista as contribuições vertidas ao sistema previdenciário posteriormente à concessão da primeira aposentadoria, isso geraria consequências práticas para o Instituto Nacional do Seguro Social.

Como corolário do deferimento dos pedidos de desaposentação está o fato de que isso legitimaria sucessivas e intermináveis renúncias de aposentadorias todo mês pelo mesmo segurado, em razão de cada nova contribuição vertida aos cofres da previdência social.

Não precisa de muito esforço cognitivo para perceber que eventual sinal positivo à desaposentadoria hoje, diante da total ausência de regulamentação do instituto, seria grande irresponsabilidade para com o País, uma vez que implicaria o colapso do sistema previdenciário brasileiro. O INSS não tem estrutura suficiente para suportar essa possibilidade de desaposentações mensais para cada um de seus milhões de segurados, fato este que ensejaria a indesejada ofensa ao princípio da eficiência, tão caro ao Direito Administrativo.

O ideal seria que a lei regulamentasse o tema, especificando interstício mínimo a ser respeitado entre um e outro pedido administrativo de renúncia ao benefício a fim de se evitar o caos no atendimento da autarquia federal.

$\mathrm{Na}$ atual conjuntura, diante da crise que o País enfrenta e do rombo na previdência social anunciado há décadas por cada governo que assume o poder, mas não resolve a celeuma, a procedência das ações de desaposentação poderia, inclusive, quebrar o INSS, não obstante os mais otimistas preguem o contrário. 


\section{CONCLUSÃO}

Após reflexões e análises que perpassaram argumentos jurídicos e procedimentais, imperioso se faz o reconhecimento de que a desaposentação não é mecanismo apto a solucionar o problema previdenciário do empregado aposentado, sob pena de verdadeira afronta a normas e princípios vigentes no ordenamento jurídico pátrio.

Não obstante a argumentação dos defensores do instituto da desaposentadoria objetivando demonstrar que esta merece prosperar, mister se faz que tracemos algumas considerações finais para sintetizar o que restou demonstrado no decorrer do presente trabalho.

Os adeptos à tese da desaposentação se utilizam do argumento do princípio da legalidade, afirmando que, se não há vedação legal ou constitucional, a desaposentação deveria ser permitida. Tratando-se, porém, de instituto de natureza eminentemente pública, a faceta que deve prevalecer é a da legalidade de direito público, não sendo lícito ao Poder Público, in casu o INSS, fazer qualquer coisa que não esteja autorizada por lei. Por isso, a ausência de previsão normativa acerca do tema consubstancia-se verdadeiro empecilho à viabilidade do instituto em análise.

Ainda que assim não fosse, a desaposentação desconsidera por completo o fato de o sistema previdenciário brasileiro ter por fundamento o princípio da solidariedade social e o regime de repartição simples no RGPS. O aposentado que regressa ao mercado de trabalho, assim como os demais contribuintes da previdência, direciona suas cotizações para fundo único do INSS, não havendo conta individualizada. Estando a previdência pautada no pacto intergeracional, a geração economicamente ativa contribui para o INSS a fim de manter as prestações pagas àqueles que estão na inatividade. Não há que se falar em vinculação das contribuições e, portanto, em relação direta entre custeio e benefício de cada segurado.

Do ponto de vista social, é plenamente crível a possibilidade de impelir aquele que está em condições contributivas perfeitas à colaboração para que se alcance o 
sucesso do sistema de seguridade, ainda que receba tão somente restritas contrapartidas, atuando, assim, de forma solidária.

Ademais, não obstante seja perfeitamente concebível a renúncia pelo aposentado à percepção da aposentadoria, esta se torna impraticável frente à impossibilidade de requerer o novo benefício mais vantajoso. Isso porque o que se objetiva com a desconstituição do ato de concessão da aposentadoria é a incorporação das novas contribuições previdenciárias; todavia, essa pretensão fere a segurança jurídica, prejudicando o outro lado da relação jurídico-previdenciária, que no caso é o Estado e, em última análise, a própria sociedade.

Imperioso salientar, outrossim, que o instituto previdenciário ora sub examine ameaça frontalmente a viabilidade atuarial do sistema. Isso porque se trata de despesa não prevista no orçamento estatal que viola ato jurídico perfeito e acabado para prejudicar o INSS. Ao se aposentar mais cedo e continuar trabalhando, o segurado sabe que sua opção terá consequências: benefício de menor valor do que se tivesse requerido a aposentadoria mais adiante; e a necessidade de continuar com as contribuições por força da obrigatoriedade de incidência do tributo. Assim, não pode ele, tempos depois, à revelia do princípio constitucional do equilíbrio atuarial, pretender requer novo benefício mais vantajoso.

Sem contar que eventual permissão à desaposentação, em razão de cada nova contribuição vertida ao INSS pelo segurado, legitimaria sucessivas possibilidades de renúncias ao benefício todo mês pelo mesmo jubilado. A previdência social brasileira não conta, hodiernamente, com estrutura capaz de absorver todas essas demandas, o que levaria, sem dúvidas, ao colapso procedimental do sistema em virtude de sua ineficiência para o atendimento aos milhões de segurados.

Diante de todo o exposto, há que se falar que a criação desse novo instituto previdenciário - a desaposentação - nada mais é do que a tentativa de amparo aos aposentados que permanecessem exercendo seu ofício e, por obrigatoriedade legal, vertendo contribuições aos cofres do INSS. A iniciativa, porém, não encontra qualquer respaldo jurídico. O que se pretende, ousamos dizer, é agradar aos aposentados à custa dos recursos públicos. 
Dessa forma, restou comprovada a inviabilidade do instituto da desaposentação, tanto do ponto de vista jurídico como da ótica procedimental, e, por consequência, a correção do acórdão proferido nos autos do RE ํㅜ 661.256 pelo Supremo Tribunal Federal. Decisão de maneira contrária afrontaria flagrantemente a Constituição Federal de 1988 e aos princípios fundantes do Regime Geral de Previdência Social.

\section{REFERÊNCIAS}

ALVES, Alessandra Cristina; GOUVEIA, Carlos Alberto Vieira de. A desaposentação frente ao princípio da solidariedade e do sistema de repartição da previdência social. In: Âmbito Jurídico, Rio Grande, XVIII, n. 140, set 2015. Disponível em: <http://ambitojuridico.com.br/site/?n link=revista artigos leitura\&artigo id=16433 >. Acesso em: 10 mar 2017.

ALVES, Carla Martins. A reversibilidade do ato jurídico da aposentadoria: desaposentação. In: IEPREV. Maio/2009. Disponível em: <http://www.ieprev.com.br/conteudo/id/13287/t/a-reversibilidade-do-ato-juridico-daaposentadoria---desaposentacao >. Acesso em: 06 mar 2017.

BARROSO, Luís Roberto. Neoconstitucionalismo e constitucionalização do Direito. Revista Jus Navigandi, Teresina, ano 10, n. 851, 1 nov. 2005. Disponível em: <https://jus.com.br/artigos/7547>. Acesso em: 02 mar 2017.

BONATO, Maria Elisa Palomine. Desaposentação: uma análise jurisprudencial. Ribeirão Preto: USP, 2013. Disponível em: $<$ http://www.tcc.sc.usp.br/tce/disponiveis/89/890010/tce-17122013094453/?\&lang=br>. Acesso em: 06 mar 2017.

BRASIL. Constituição Federal. Brasília: Senado Federal, 1988. Disponível em: < http://www.planalto.gov.br/ccivil_03/constituicao/constituicaocompilado.htm>. Acesso em: 02 mar 2017.

Decreto-Lei no 5.452 de $1^{\circ}$ de maio de 1943. Aprova a Consolidação das Leis do Trabalho. In: Diário Oficial da República Federativa do Brasil, Rio de Janeiro, RJ, $1^{\text {o }}$ maio 1943.1 Disponível em: <http://www.planalto.gov.br/ccivil_03/decreto-lei/Del5452.htm>. Acesso em 15 mar 2017. 
Federativa do Brasil, Brasília, DF, 6 maio 1999. Disponível em: <http://www.planalto.gov.br/ccivil_03/decreto-lei/Del5452.htm>. Acesso em 15 mar 2017.

. Lei no 8.213 de 24 de julho de 1991. Dispõe sobre os Planos de Benefícios da Previdência Social e dá outras providências. In: Diário Oficial da República Federativa do Brasil, Brasília, DF, 24 jul. 1991. Disponível em: <http://www.planalto.gov.br/ccivil_03/leis/L8213cons.htm>. Acesso em 13 mar 2017.

. Tribunal Superior do Trabalho. Orientação Jurisprudencial no 177 da SDI-1. Disponível em: <http://www3.tst.jus.br/jurisprudencia/OJ_SDI_1/n_s1_161.htm\#TEMA177>. Acesso em: 13 mar 2017.

. Tribunal Superior do Trabalho. Orientação Jurisprudencial no 361 da

SDI-1. Disponível em: <http://www3.tst.jus.br/jurisprudencia/OJ_SDI_1/n_s1_361.htm\#TEMA36>. Acesso em: 14 mar 2017.

BUENO, Luiz Henrique Picolo. Breves considerações acerca do instituto da desaposentação. In: Âmbito Jurídico, Rio Grande, XV, n. 105, out 2012. Disponível em:

$<$ http://www.ambitojuridico.com.br/site/index.php/\%3C?n link=revista artigos leitura\&artigo id=12362>. Acesso em: 03 mar 2017.

CASTRO, Carlos Alberto Pereira de; LAZZARI, João Batista. Manual de Direito Previdenciário. 16. ed. Rio de Janeiro: Forense, 2014.

COLNAGO, Lorena de Mello Rezende. Desaposentação. In: Revista de Previdência Social, ano 39, n. 301, p. 793, dez. 2005.

DALLEASTE, Fábio Soares. Desaposentação: uma abordagem conceitual. Porto Alegre: UFRS, 2014, p. $15 . \quad$ Disponível em: $<$ https://www.lume.ufrgs.br/bitstream/handle/10183/101372/000931299.pdf?sequenc $\mathrm{e}=1>$. Acesso em: 04 mar 2017.

GAMA, Lorena Matos. A possibilidade da garantia ao emprego do trabalhador aposentado e portador de doença ocupacional. In: Âmbito Jurídico. Disponível em:

$<$ ttp://www.ambitojuridico.com.br/site/index.php?n_link=revista_artigos_leitura\&artigo_id=10987\&revist a_caderno=25>. Acesso em: 03 mar 2017.

IBRAHIM, Fábio Zambitte Ibrahim. Curso de Direito Previdenciário. 16. ed. Rio de Janeiro: Impetus, 2011.

Desaposentação: O Caminho Para Uma Melhor Aposentadoria. 5. ed. Rio de Janeiro: Impetus, 2011. 
MARCELO, Fernando Vieira. Desaposentação: Manual Teórico e Prático para o Encorajamento em Enfrentar a Matéria. 3. ed. São Paulo: JH Mizuno, 2014.

MARINELA, Fernanda. Direito Administrativo. 6. ed. Niterói: Impetus, 2012.

MARTELLO, Alexandro. Previdência tem déficit recorde de R\$ 149,7 bilhões em 2016. In: Portal G1, jan/2016. Disponível em: < http://g1.globo.com/economia/noticia/rombo-da-previdencia-social-cresce-745-em2016-e-bate-recorde.ghtml>. Acesso em: 15 mar 2017.

MARTINEZ, Wladimir Novaes. Desaposentação. 7. ed. São Paulo: LTr, 2015.

Princípios de Direito Previdenciário. 6. ed. São Paulo: LTr, 2015.

- Renúncia e irreversabilidade dos benefícios previdenciários.

Suplemento Trabalhista — LTr: São Paulo, n. 4, 1987.

Reversibilidade da prestação previdenciária. Repertório de Jurisprudência, IOB. São Paulo: IOB, 1988.

MARTINS, Sérgio Pinto. Direito da Seguridade Social. 27. ed. São Paulo: Atlas, 2009.

SERAU JÚNIOR, Marco Aurélio. Desaposentação: Novas perspectivas teóricas e práticas. 4. Ed. Rio de Janeiro: Forense, 2013.

SIMÕES, Odair Raposo. A Desaposentação sob a Ótica do Direito Atual. São Paulo: Nelpa, 2013.

TERAN, Teddy Arthur Monteiro. Uma análise da desaposentação frente aos princípios constitucionais previdenciários. Revista Jus Navegandi, março/2015. Disponível em: <https://jus.com.br/artigos/37196/uma-analise-da-desaposentacaofrente-aos-principios-constitucionais-previdenciarios>. Acesso em: 11 mar 2017. 